\title{
Marketization and Education of Schooling in Urban China
}

\author{
Ruihan Su \\ School of Beijing Normal University Zhuhai, Zhuhai, 519000, China \\ ruihan.susu@icloud.com
}

Keywords: Education policy, Urban China, Marketization

\begin{abstract}
Since 1970s, China made a change of successful economic transformation; China's education also experienced great change because of marketization and reform. The policies at different time reflect the strategies of government to make use of the market economy and create more chances for their people from the education resources. This paper aims to analyse and present the effect of marketization in educational field of urban China.
\end{abstract}

\section{Introduction}

Looking through the education history of China, private schools and public schools coexisted in the past two thousand years. Unlike the time before the founding of People's Republic of China, there has been a strong transformation since the 1970s. Many schools in the adoption of a centralization policy converted into the system of diversification and decentralization. The marketization of schooling leads to an inevitable change on education in urban China. The principle goal of this paper is to examine the influence of marketization and whether it is viable to adopt marketization and competition to Chinese education.

This paper is framed by five parts. It starts with a general introduction of the subject. Then it explains the development of changing Chinese Education Policy. In this part, the author highlights dramatic reform since 1949, and new educational form generated by education marketization. The third part discusses the influence and result from marketization, by presenting different views from proponents and opposition. The forth part explores the appropriate approach adopt education to marketization in the future challenge in China. The last part is the summary, which also makes an exploration of future development of Chinese education.

\section{The changing Policy of Chinese Education}

Education has been placed in a high value position in China for a long history, whether officially run schools or private schools. Confucius and Lao Tzu were the first person who ran private schools, which broke the monopoly of government-run schools at that time [10]. Since 1949, with the founding of the People's Republic of China, a big change occurred in Chinese education. Almost all private schools were quickly revered to government-control schools. Thus, the collective or nationalist ideology controlled each part of China, including education, between 1949 and early 1980s, and traditional private education vanished in the Chinese education system from 1949 to early 1990s [10]. The government-run system gave a relatively tight control over marketization and competition in schooling [7].

In 1978, Deng Xiaoping and his followers introduced economic reform to China [12] and made a change by a successful economic transformation with "opening-up to the outside world". "Private businesses were allowed to operate for the first time since the Communist takeover, and they gradually began to make up a greater percentage of industrial output” [2]. Although radical or "conservative" power could still be found in Chinese Community Party at 1978, the government gave a further detail, "Provisional Regulations on the Establishment of Schools by Societal Forces" [10], to encourage non-government educational institutions to be included in the educational system.

Although non-government schools in urban China do not exist after the founding of the People's Republic of China, the policy "Provisional Regulations for the Establishment of People-Run 
Schools of Higher Education" promulgated in 1993 [7] by the State Education Commission actuated the growth of private schools. In late 1993, "The program for Reform and the Development of China's Education” suggested that the government gave a fully support for nongovernment institution to build schools. It was estimated that there were around 500 registered nongovernments schools in urban areas in 1994, and the number increased to about 4000 at the end of 1997 [6].

Now, there are mainly three types of schools in China in terms of who runs the school: Government, people (community), private (individual/ group). However, different kinds of nongovernment schools are more popular in urban areas, and the traditional private schools can be found commonly in the advanced area in China [10]. Also, another type of non-government school, named affiliated schools, is becoming more popular in the south part of China. These kind of schools draw on the established reputation of the parent key government schools together with the teaching, management resources. They charge very high tuition fees from students, which enable them to pay high salaries to collect good teachers and put more fund into the development of facilities. These are the main aspects for the non-government schools to compete with government school.

\section{Results from marketization}

With the flourishing of the market economy, educational development in mainland China especially in urban China has been effected. In 1985 Central Committee of the CCP indicated to increase the variety of educational services [7] by

encouraging all democratic parties, people bodies, social organizations, retired cadres and intellectuals, collective economic organizations and individuals subject to the Party's and governmental policies, actively and voluntarily to contribute to developing education by various forms and methods [11].

Like the emergence of the market economy, marketization in education area arouses many arguments among Chinese scholars.

One of the results of marketization is "school choice". Parents choose schools for several reasons, such as looking for higher-quality school or attracting by specialty programs [10], like key government schools with higher quality teaching staffs, better facilities and more government investment.

In order to do so, most Chinese families save for children's education and parents are willing to consume their savings on education. Thus the high cultural value of education is a significant social support. Moreover, a reform in educational finance from 1980s leads to a factor that there exists big gap among different regions of China in terms of economic as well as education. Large disparities in teaching quality and other infrastructure between key schools and regular schools are obvious. To enroll in good schools, competition of education among students starts in their early life, even before the primary school. Likewise, parental choice has influence on schools. Many schools and universities have reconstructed their "disciplines and specializations to cater for newly emerging needs from the market" [8]. Thus the schools without attractive courses cannot win at this stage.

Another influence points out by Mok and Wat [7] is that private schools offer diversified courses to encourage students' development due to autonomy of running schools. To keep pace with the changing market context, schools develop elastic methods in curriculum arrangement. These courses enable students to acquire the popular skills and knowledge, which are needed in the free labor market. A manager from Chinese higher education institution believes that embarking on the business and commercial activities would provide a good chance for universities' scholastic and research activities [7]. Ren Yanshen, Vice-Secretary of the Party Committee of Beijing University said that:

This will also 'play a reverse role' as commercial activities begin to support the university's scholastic activities. The financial income obtained will be used to improve teaching 
conditions, provide teachers and staff with opportunities to exercise their professional skills, and relieve them of any anxieties about their livelihood [11].

There is an increasing number of higher education institutions enter into market economy by doing business and commerce to create additional funds to underpin research and teaching facilities. This is a positive aspect for marketization and competition in education. As many professors indicates in his paper that more money can be allocated to increase teaching and research activities, provided schools get extra income through the venture in commerce. Mok also points out in his study that the competition is a way to "raise teachers' sense of responsibility toward teaching"[7]. From this it follows that the marketization "is used to inspire excellence and to encourage everyone to put all their energies into teaching and research"[8].

Besides higher education, marketization and competition are found in primary and secondary schools. Data collected in Shanghai secondary schools shows that the profit increases from 1.16 billion yuan in 1988 to more than 2 billion yuan in 1990 because of marketization in education. It is also reported that more than 80 per cent primary and secondary schools in the mainland China have their own companies to support their teaching. As a result, the opportunities in market economy of education provide schools and universities chances to improve their teaching and research facilities.

However, education marketization has intensified an account of education inequality. With frequently changing market, people would suspect that whether it is reasonable to adopt education in the market economy. Zhang, vice minister of Education department, argues that education should only rely on government [10]. He points out the marketization inevitably brings about polarization, which damages social justice. The influence from market economy on people's values is not positive. Education, however, essentially aims to reduce the negative effect and promote harmony in society. Fu [4] argues market economy only benefit the rich, so over-relying on marketization would make the poor cannot afford the tuition fee.

From these arguments it follows that schooling in China has been impacted by marketization. Students are benefit from the competition among different schools, as they can choose what they want and need. The improving teaching facilities and qualities also satisfied the needs from parents and students. For higher education, marketization brings fund to support universities' teaching and research. Nevertheless, there are many different voices oppose the education marketization, since an endless competition would widen the gap between the rich and the poor. Some parents cannot afford their children to a better school, which the polarization leads to social injustice. Therefore in the next part, it moves on to the future of Chinese education market by comparing schooling of other countries.

\section{The future of marketization}

Education marketization is global phenomenon, in which China play a part of it. To explore the development in the future, we should draw on the experiences from other countries, especially the elite and high quality teaching.

Private schools in UK are considered as autonomous and strongly led governing by clear constraining environment, while public schools are lacking in autonomy...school goals are heterogeneous, unclear and undemanding [3]. In US, people confirm the significance of education competition, but they confirm and recognise that there exist positive and negative impacts in different states [1]. However, Elacqua points that out in Chill polarization exists in poor and rich families. Private schools are controlled by hierarchical system, and some of the schools "attracting the social elite by charge fees requiring children to sit entrance exams" [1]. Hence, the gap of wealth may brings social injustice, which widens the gap between the fortunate and the forgotten, which makes society progressively less equal over time.

Comparing with different countries, the influences of schooling by marketization in China share the similar characters. Parental choice offers students chance for better study environment and teaching quality, but at the same time it deprives relatively poor students' chances to enter into the higher reputation schools. 
Under these conflicts, is it viable to apply Chinese education to the setting of the market economy? Many authors offer various opinions. For instance, Tsang [10] suggests marketization reminds Chinese educational leaders to focus on the practical skills like critical thinking and problem solving abilities, which improve the competitiveness of Chinese educational system in the global economy background. So far, both government and private schools are driven by examination-oriented system [10], so it is hard to convert the teacher-centered pedagogy to the students-centered one. However, this is not to say that there is no attempt to alter the situation. Some private schools, for example, adopt special curriculum, which are attractive to some parents. Fan [5] claims that education marketization enhance the internal dynamics of the schools, optimise school structure, accelerate the pace of school-opening, and develop the students' competition concepts. Allen and Burgess [1] also offer the good points of marketization in their work that parental choice offers a chance for popular schools to grow; choice from parents "has the potential to make schools to achieve efficiency gains" [1], as it connects school popularity and income with the quality of teaching and facility.

There are, however, some restrictions of education competition, as Fan [5] reminds that it is unreasonable to accept all competition situations unconditionally. He suggests competition is not the fundamental impetus to the development of education; school is the independent legal entity, but not as independent as enterprise in self-financing. Also $\mathrm{Fu}$ [4] emphasises that competition among teachers certainly arouse their enthusiasm, but it should be preceded from the national condition, and take the basic characteristics of teacher into account. Admittedly, competition do more harm than good, as students should be guided in positive way [5].

Therefore, Chinese education policy is enacted in accordance with Chinese socialist economic policy. In the inevitable trend of the market economy, the state allows the room for non-government social form to become included, but it does not mean that the government has relinquished its monopolistic role [5]. The strategies of decentralization and marketization in China are used to improve the national "financial situation and enhance the efficiency and effectiveness in the use of its resources in the face of financial stringency" [9]. The application of the policies shows an intention to employ market force from non-government source in mobilizing more educational services and generate more study chance for the students [9]. In any case, the government source plays a positive role in education.

\section{Conclusion}

Education marketization is a global trend. Comparing with different countries, China shares the similar characters and troubles in terms of influences of schooling by marketization. Thus, to deal with this issue, Chinese education policy should be enacted in accordance with Chinese socialist economic policy. The application of the policies shows an intention to employ market force from non-government source in mobilizing more educational services and generate more study chance for the students.

\section{References}

[1] Allen, R. And Burgess, S. (2010) The Future of Competition and Accountability in Education.

[2] Brandt, L., et al. (2008) China's Great Transformation, Cambridge, Cambridge university press.

[3] Chubb, J. E. and Moe, T. M. (1988) Politics, Markets, and the Organization of Schools, The American Political Science Review, 82(4): 1065-1087

[4] Fu, J. (2006) Why Education can’t rely on Market Economy. Xinhuanet, [online] 14 June 2006. Available at: < http://news.xinhuanet.com/comments/2006- 6/14/content_4694562.htm> [Accessed 7 December 2013].

[5] Fan, G., (1995) A Perspective on "Education Competition” Theoretical Research. Theory and practice of education, 15(6): 33-35. 
[6] Ministry of Education (1998). Educational statistics yearbook of China 1997. Beijing, China: People’s Education Press.

[7] Mok, K. H., \& Wat, K. Y. (1998) Merging of the public and private boundary: education and the market place in China. International Journal of Educational Development, 18(3): 255-267.

[8] Mok, K. H. (2000) Marketizing higher education in post-Mao China.International Journal of Educational Development, 20(2): 109-126.

[9] Ngok, K. (2007) "Chinese education policy in the context of decentralization and marketization: Evolution and implications”, Asia Pacific Education Review, 8(1): 142-157.

[10] Tsang, M. (2001) “School Choice in People's Republic of China” Occasional Paper 9, National Center for the Study of Privatization in Education, Columbia University, New York.

[11] Wei, Y. and Zhang, G. (1995) A historical perspective on non-governmental higher education in China. Paper presented to the International Conference of Private Higher Education in Asia and the Pacific Region, November, The University of Xiamen, China.

[12] Yao, Ruobing (1984) Zhongguo Jiaoyu 1949-1982 (China’s Education 1949-1982). Wah Fong Bookshop Press, Hong Kong. 